\title{
The market, utilitarianism and the corruption argument
}

\author{
Mozaffar Qizilbash $^{1}$
}

Received: 3 October 2017 / Accepted: 13 June 2018 / Published online: 6 July 2018

(c) The Author(s) 2018

\begin{abstract}
Some philosophers argue that if market reasoning exceeds certain limits, it may 'corrupt' certain cherished values; and the tendency of modern economics to encourage such 'corruption' has its roots in its normative foundations. Michael Sandel goes further and suggests that this tendency can be traced to utilitarian reasoning. I argue that the desire to restrict the scope of economics can be found in the utilitarian origins of neoclassical economics. The argument that market reasoning may 'corrupt' various values has gained credence from the work of market enthusiasts like Gary Becker but does not apply to the traditional framework of welfare economics. Furthermore, if economists adopt the informed desire or preference view of welfare endorsed by some utilitarians, certain arguments advanced by these philosophers can be rebutted.
\end{abstract}

Keywords Market · Welfare economics · Utilitarianism · Preferences · Information

JEL Classification A12 $\cdot$ A13 $\cdot$ B13 $\cdot$ D61 $\cdot$ D63 $\cdot$ I30 $\cdot$ I31 $\cdot$ I38

'It is the lowest rank of feelings which we treat here. The calculus of utility aims at supplying the ordinary wants of man at the least cost of labour' Jevons (1871, 93).

\section{Introduction}

The scope of economics has been much expanded over time, notably due to the pioneering works of Gary Becker. Becker argued that the economic approach can be applied to all areas of human behaviour. In recent years, some moral and political philosophers, notably Anderson (1993) and more recently Sandel (2012, 2013), have raised questions about the limits of the market. They have argued that modern

Mozaffar Qizilbash

mozaffar.qizilbash@york.ac.uk

1 University of York, York, UK 
economics encourages the spread of 'market reasoning' to areas where it was not previously applied and where, arguably, it has no place. In his version of this argument, Sandel traces the tendency of economics to encourage market reasoning to the way economists think about value and to the fact that, even if some economists are aware of the limitations of utilitarian reasoning, many of the normative conclusions economists reach rest on utilitarian assumptions (Sandel 2013, 123). In her version of the argument, Anderson explicitly argues that the spread of market reasoning outside certain domains is corrosive of other values. Sandel calls this the 'corruption' argument. This argument suggests that modes of reasoning that are appropriate to 'lower-order goods' when deployed to reason about 'higher-order goods' degrade those goods. Arrow (1997) noted that arguments of this sort have a pedigree. He wrote that: '[o]ne of the oldest critiques of economic thinking has been its perceived disregard of the deeper and more sacred aspects of life' (Arrow 1997, 757). Furthermore, some economists (e.g. Besley 2012; Bruni and Sugden 2013, 142) have responded thoughtfully to recent versions of these arguments and have argued that economists should engage with them. Indeed, Bruni and Sugden $(2013,141)$ associate arguments of this sort with virtue ethics in moral philosophy and 'a radical critique of the market economy' according to which 'economics is complicit in an assault on virtue and on human flourishing'. ${ }^{1}$ Finally, Sandel $(2013,139)$ has also suggested that to address the moral limits of the market economics needs to 'reconnect with its origins in moral and political philosophy'.

In this paper, I provide a distinct response to some of the arguments in this literature which connects them to the origins of neoclassical economics in utilitarianism. While the claims made by these philosophers are sometimes seen as very critical of economics, they are very close relatives of views expressed by William Stanley Jevons. Jevons' The Theory of Political Economy was heavily influenced by the classical utilitarians, notably by Jeremy Bentham and J.S. Mill. Jevons took from the utilitarians the view that human beings are motivated by the pursuit of utility or pleasure, and based his analysis on this insight. One important difference between Bentham's and Mill's utilitarianism is that Mill $(1962,259)$ distinguished between different qualities of pleasure: he thought that there were certain pleasures which involved the use of the 'higher faculties' and that even a small amount of these was preferable to a very large amount of some 'lower-order pleasure'. Jevons took up Mill's distinction between higher and lower pleasures and argued that political economy should only be concerned with the lowest order of pleasures. Clearly, to the degree that a stringent restriction on the scope of the discipline is here found at its utilitarian roots, it seems unlikely that the goal of expanding the scope of economics and market analysis can be traced, without controversy, to those roots.

\footnotetext{
1 This paper is restricted in scope in as much as it only considers some of the arguments which critics like Anderson and Sandel advance. It is also restricted in scope in as much as it only considers one theme of this special issue-i.e. virtue and the 'virtue ethics critique' of economics. I do not discuss issues relating to motivation, incentives and awards and which are relevant to the theme of 'prizes' which are discussed by some of these critics of economics (see, for example, Sandel 2012, 107-130).
} 
In one statement of his views, Sandel $(2013,122)$ argues that the apparent inability of modern economics to define the limits of market reasoning originates in part from its attempts to remain 'value-free'. In this paper, I argue - to the contrary - that the standard or traditional framework of welfare economics involves plural valuesnotably efficiency and equity inter alia - though in modern times-certainly since the contributions of Hicks (1939) — it has eschewed any explicit commitment to a moral theory such as utilitarianism. The fact that modern welfare economics does not endorse any particular moral theory has not, of course, stopped particular economists from endorsing some or other moral theory. In the second half of the twentieth century (Harsanyi 1953, 1955, 1982, 1995, 1997 inter alia) famously endorsed a version of utilitarianism. He also endorsed the informed preference view of welfare which is sometimes linked to Mill's utilitarianism. In this paper, I argue that even if some economists who are 'market enthusiasts' have proposed the more widespread use of market analysis and of the market as an allocation mechanism in various contexts, the standard framework of welfare economics itself does not necessarily do so, nor does it encourage it. The well-known case in favour of the market-which is usually advanced in terms of the first fundamental welfare theorem-is an argument for the efficiency of the market and is always qualified by the observations that there are conditions under which markets will not produce efficient results and that market equilibrium might involve an inequitable distribution of goods. I argue that if this theorem is understood in terms of the informed (or rational) desire or preference view of welfare, economists can respond to some criticisms that Anderson and Sandel advance. However, this defence of welfare economics is qualified by the fact that people's ordinary preferences are not necessarily informed or rational. If preferences are ill-informed or irrational, then markets might fail to deliver efficiency and there is a case for government intervention. I also consider the 'corruption' argument and the reasons why Anderson thinks welfare economics inappropriately encourages the spread of market reasoning. I argue that Anderson's case is weaker if welfare is understood in terms of informed preference, and that economists have thought about, and can respond to another of the issues ('commodity fetishism') that Anderson is concerned about. Anderson's argument is, I suggest, best understood as an argument against market enthusiasm rather than against traditional welfare economics.

Before presenting the argument of the paper in detail, I should also explain how it differs from one previous response to Sandel's version of the argument from within the economics profession. In his excellent paper, Tim Besley provides a survey of a very wide range of work in economics which is relevant to Sandel's discussion. He notes that in Sandel's version of the argument 'the economics profession comes in for a fair bit of stick' and that '[e]conomists are accused of having views about markets which lead to repugnant conclusions' (Besley 2012, 479). He also worries about the dangers of 'taking examples and quoting selectively, and then characterising this as the views of economists in general'. I share this concern. However, Besley adds that he did 'recognize all the positions that' Sandel 'attributes to members of the economics profession, i.e. they are reflective of what some (perhaps even many) economists believe' (Besley 2012, 479). Here I part ways with Besley: one of my claims is that because Sandel mischaracterises one of the basic tenets of welfare 
economics and interprets it in terms of its utilitarian heritage part of his characterisation of 'economics' is misleading and unhelpful.

The paper is structured as follows: in Sect. 1, I introduce the informed desire or preference view of welfare and make some preliminary comments about 'economics' and the relationship between preferences and commodities; in Sect. 2, I argue that Sandel mischaracterises a central result in welfare economics and explain various alternative defences of the market; I discuss the 'corruption' argument and attempts to distinguish 'higher' and 'lower' goods which aim to restrict the scope of the market or of economics as a discipline in Sect. 3; and Sect. 4 concludes.

\section{Informed preference, welfare and the 'economic approach'}

Economists sometimes equate people's preferences with their tastes and welfare with the satisfaction of preferences. The informed desire or preference view suggests that the fulfilment of actual desires or preferences does not constitute well-being: well-being is constituted by the fulfilment of informed desires or preferences. This view of welfare was first explicitly advanced by Henry Sidgwick (1981), though it is implicit in John Stuart Mill's well-known discussion of 'higher-order' and 'lowerorder' pleasures. Mill famously wrote that: '[o]f two pleasures, if there be one to which all or almost all who have experience of both give a decided preference, irrespective of any feeling of moral obligation to prefer it, that is the more desirable pleasure' (Mill 1962, 259).

In modern utilitarian thought in the second half of the twentieth century, a version of the informed preference or desire view was endorsed in economics by Harsanyi $(1953,1955,1982,1995,1997)$ and in moral philosophy by Griffin (1986) inter alia. ${ }^{2}$ Different versions of this account articulate slightly distinct versions of the requirement for desires or preferences to be informed. In one version, Harsanyi refers to a person's 'true preferences', the 'preferences he would have if he had all the relevant factual information, always reasoned with the greatest possible care, and were in a state of mind most conducive to rational choice' (Harsanyi 1982, 55). Here, as in other formulations, the relevant preferences are in important respects both informed and rational. Harsanyi distinguishes 'true preferences' from a person's 'manifest preferences' which are 'his actual preferences as manifested by his observed behaviour, including preferences possibly based on erroneous factual beliefs, or on careless logical analysis, or on strong emotions that at the moment greatly hinder rational choice' (Harsanyi 1982, 55). On a later version of Harsanyi's view, a person's informed preferences are those 'hypothetical preferences he would have if he had all the relevant information and had made full use of this information' (Harsanyi 1997, 133).

\footnotetext{
${ }^{2}$ Hausman and McPherson (2009) and Hausman (2012), chapters 7 and 8 actually argue that the economics profession appears to endorse a version of the informed preference view, but that this view is false and should be rejected. There is not adequate space here to discuss Hausman and McPherson's claims.
} 
By way of contrast, Griffin's view focusses on desires rather than preferences. On one version of his information requirement, a desire is informed when it is 'formed by appreciation of the nature of its object, and it includes anything necessary to achieve it' (Griffin 1986, 14). In another version, informed desires are those which avoid all the problems he finds with actual desires, and these include faults which derive from lack of information as well as from logical error inter alia (see Griffin 1986, 12-14). Once more the information requirement includes a rationality condition and informed desires are also in important respects rational. Indeed, I will sometimes say, rather loosely, that the desires or preferences involved in these views are both informed and rational, though the relevant form of rationality involved is usually part of the information requirement. One element that is common to Griffin's view and Harsanyi's later statements of his view is that they both endorse a list of those things that make a human life go better. In Griffin's case, the relevant things'prudential values' - are the objects of informed desire. These include: autonomy and liberty; accomplishment; enjoyment; deep personal relations of the sort we find in friendship and love; and understanding (Griffin 1986, 67-68). Harsanyi advances a similar list. He thinks of prudential values as the objects of 'basic desires'. He lists the following: '[m]aterial comfort; physical security; freedom to control our own lives; good health; a job suitable for our personal abilities and interests; deep personal relations in mutual love, in marriage and in true friendship; to have children and to be a good parent; to achieve better understanding of the world and of our place in the world; enjoyment of beauty in nature and in art; to have worthwhile accomplishments of some kind; and to make our own behaviour consistent with our moral values' (Harsanyi 1995, 323).

Are these accounts of welfare and the lists of values they advance compatible with standard economics? This might appear to be an odd question to ask, since Harsanyi was an economist (and won the Nobel prize in economics). I address it, nonetheless, since it might be argued that Harsanyi's position is in some way exceptional. Furthermore, the papers in which Harsanyi advances his list of prudential values emerged very late in his career and differ in significant ways from his earlier statements of his view (e.g. Harsanyi 1953, 1955). In what follows, I focus on one characterisation of 'economics' which Sandel discusses: Gary Becker's 'economic approach to human behavior' (Becker 1976). I do not do so with a view to arguing that Becker's approach is an informed desire or preference view, but because, like some versions of that view, it endorses the idea that there are some fundamental or basic objects of desire or preference however diverse our actual preferences might appear.

In characterising the discipline, Becker distinguishes economics from other disciplines in terms of its commitments to: maximising behaviour; the use of the market as an allocation system; and stable preferences. Of these, the crucial assumption for the present discussion is the assumption of stable preferences. According to Becker, this assumption is defensible because certain objects of preference remain stable however much our actual preferences change over time. The relevant preferences are not preferences over 'market goods such as oranges, automobiles, or medical care' but relate to the 'underlying objects of choice' which are associated with 'fundamental aspects of life, such as health, prestige, sensual pleasure, benevolence, 
or envy, that do not bear a stable relation to marketable goods and services' (Becker 1976, 5). Clearly, this list of the fundamental aspects of life is not far removed from the lists of prudential values that Harsanyi and Griffin endorse. There are obvious differences in as much as Becker's list covers objects such as envy which is clearly not a prudential value. My claim is only that there is no reason why economists cannot use such lists. In advancing his list of prudential values, Harsanyi argues that all of them make our lives go better and this is because 'all human beings have much the same basic biological and psychological needs and so have much the same basic desires' (Harsanyi 1997, 139). As regards the stability of some objects of desire and preference, there seems to be little to separate Becker and Harsanyi here and this aspect of Becker's 'economic approach' is clearly compatible with Harsanyi's later versions of his account.

In his characterisation of the economic approach, Becker makes the market central. He is - what I shall call-a 'market enthusiast' within the discipline. By a 'market enthusiast', I have in mind someone who has argued for the use of market analysis beyond its traditional domain either in economic analysis or in policy discussions. Sandel's focus on Becker's work in characterising the 'economic approach to life' (Sandel 2012, 47-51) means that he takes 'market enthusiasm' to be representative of economics as a whole. Becker mixes his market enthusiasm with the view that the discipline of economics is relevant to all human behaviour and falls at the opposite end of the discipline to Jevons in terms of his view of its ambitions and scope. Of course, not all modern economists are market enthusiasts, nor would they necessarily take seriously the idea of an economic analysis of all areas of human behaviour including areas such as marriage. For example, in one response to Becker's characterisation of the 'economic approach' and his theory of marriage, Amartya Sen $(1984,372)$ suggested that 'the approach does remain rather crude'. In the specific case of its application to marriage, he added: '[c]onceptualising marriage as a "two person firm with either member being the 'entrepreneur' who 'hires' the other" and "receives residual profits" can perhaps be said to be a rather simple view of a very complex relationship'. So it is important to note that Becker's characterisation of the economic approach provoked considerable controversy within economics and that there are economists who did not, and do not, share his market enthusiasm.

Having noted the fact that Becker may not be a 'representative' economist, I should mention another relevant discussion in economics which has been influential in characterising 'commodities' or 'goods'. In a well-known discussion, Lancaster (1966, 133; see also Gorman 1956) distinguished between goods and their characteristics. He suggested that 'a meal (treated as a single good) possesses nutritional characteristics but it also possesses aesthetic characteristics, and different meals will possess these characteristics in different relevant proportions'. These characteristics are, on his account, the objects of preference. He writes that: '[u]tility or preference orderings are assumed to rank collections of characteristics and only to rank collections of goods indirectly through the characteristics they possess'. Lancaster's influential analysis, like Becker's approach, does not treat commodities as the ultimate objects of preference. While standard texts in economics do not say much about the nature of commodities or goods, a variation of this analysis of how to distinguish goods - restricted to their physical characteristics-appeared in a canonical 
treatment of competitive markets when Arrow and Hahn $(1971,17)$ wrote that: '[a] good may be defined by its physical characteristics, its location in space, and the date of delivery'. Certainly, the characteristics of goods-as Lancaster understood them-link more directly to the 'fundamental aspects of life'-such as health and pleasure - and indeed to the objects of informed desire or preference than commodities themselves. Of course, there may be characteristics of a good which are neither fundamental aspects of life nor prudential values: a car might be desired because it is 'flashy'. Nonetheless, the characteristics of commodities provide a bridge between commodities and the ultimate objects of informed preference or desire. Even the desirability of a 'flashy' car might ultimately derive from a desire for status or respect in society, and such status or respect might be the sort of thing that might be a fundamental aspect of life or prudential value. Before moving on, I should add that while I have argued that informed desire or preference views are not incompatible with economic analysis, that is quite different from claiming that all economists will or should necessarily endorse them. Some economists might well find some developments of the informed desire view unattractive (see, for example, Sugden 2000), just as some might object to Mill's distinction between higher- and lowerorder pleasures (see, for example, Layard 2005, 22-23). So while I will argue in this paper that the informed desire or preference view might help economists address some criticisms, I do not claim that all economists would or should necessarily wish to endorse this view to address them.

\section{Alternative defences of the market: efficiency, welfare and opportunity}

In discussing the case for the market - and specifically the case for market allocations over queues-Sandel $(2012,29)$ mentions two lines of argument: one of which he terms 'libertarian', while the other is 'utilitarian'. I focus here on the second of these. Sandel's thought is that market exchanges allow for both parties to a transaction to benefit. This thought is in itself unproblematic as it is an expression of the familiar idea that markets facilitate mutually advantageous transactions. But then Sandel adds that as a result the market improves the welfare of both parties- thus increasing total 'collective well-being and social utility' (Sandel 2012, 29). This additional claim suggests that in making the case for the market, economists are utilitarian or at least relying on some sort of moral theory. Sandel thinks that this line of argument also suggests that if the use of the market mechanism spreads to areas where it is not currently in operation, then social welfare will increase. This looks like an argument for the commodification of some areas of life on utilitarian grounds.

But this is not the standard view in welfare economics. The case for the market in welfare economics is Paretian rather than utilitarian: it says that, under certain conditions, market allocations are Pareto efficient-in the sense that one cannot improve one person's welfare without worsening someone else's. In standard statements, the first fundamental welfare theorem states that, under well-known conditions, in a market equilibrium there is no alternative distribution which leaves at least one 
person better off without making someone else worse off. And, in fact, even in Sandel's book (Sandel 2012, 29-30) the economics text book he cites makes the case for the market in terms of efficiency rather than on utilitarian grounds. Sandel's reference to utilitarianism here is mistaken and misleading. Furthermore, the standard case for the market in welfare economics is usually qualified by the observation that Pareto efficient allocations can be inequitable. The case for the market in welfare economics thus recognises multiple values without making any claims about their relative weight. That is one reason why welfare economics does not and cannot on its own adjudicate on proposals about the scope of the market. Its failure to do so appears to be a disappointment for Sandel, but it relates to one of the argumentsabout the potentially unfair nature of market allocations - that Sandel $(2012,110)$ himself makes central in his book. On the question of what goods are and are not commodities, standard results in welfare economics do not take a view. In standard expositions of the first fundamental welfare theorem, for example, the vector of commodities is simply taken as given. For example, Arrow $(1951,511)$ merely supposes that there are $n$ commodities in his exposition (see also Qizilbash 2005).

In a more recent statement, Sandel $(2013,122)$ argues that the failure of economists to take a view on which 'goods are up for sale' stems from their desire to pursue a value-free science. But if I am right, part of the reason that economics as a discipline cannot make claims of this sort is that while it recognises plural values (efficiency and equity inter alia), the discipline does not itself take any allencompassing view of how to rank values of the sort which a moral theory such as utilitarianism might provide. Ironically, one way in which economics could do some of the work that Sandel requires of it would be to endorse some form of moral theory like utilitarianism. Indeed, on the version of utilitarianism which Harsanyi endorses - which recommends a moral code or set of rules which maximises average welfare-one might define the limits of markets on the basis of this moral principle. But, not all economists are utilitarians and economists take different views of morality, and the discipline allows them to do so. In this respect also economics is pluralist: it allows economists to take quite different views about morality. On this basis, one would also expect some economists to be more enthusiastic about markets than others and that is indeed the case. Many of the economists Sandel cites are market enthusiasts. The spread of the market into realms where it has traditionally not had any significant role suggests that market enthusiasts are succeeding. But if that is the right reading of the situation, the issue that Sandel is raising is not about the discipline as a whole or about welfare economics. Rather it is about the success of market enthusiasts. If they are concerned about the degree of that success, Sandel and others like him might be better served by discussing at greater length and supporting the arguments of those within economics who are less enthusiastic about the market. $^{3}$

Let us suppose then that Sandel has simply mischaracterised the case for the market in economics, as I think he has. Is there anything else we can learn from

\footnotetext{
3 Sandel does, nonetheless, sometimes invoke economists in support of his own arguments (see, for example, Sandel 2012, 38).
} 
his discussion? In thinking about this point, consider the standard interpretation of Pareto efficiency in economics:

(1) A distribution is Pareto efficient if no alternative distribution makes at least one person better off, while nobody else is worse off.

This is the interpretation of the Pareto criterion I have thus far used in characterising the first fundamental welfare theorem. It characterises Pareto efficiency in terms of welfare. Alternatively, Pareto efficiency can be characterised in terms of preference as follows:

(2) A distribution is Pareto efficient if no alternative distribution allows at least one person to reach a more preferred point, while nobody else is at a point which is less preferred.

Now often economists take (1) and (2) to be equivalent. The equivalence is sometimes implicitly assumed. This assumption in turn implies acceptance of the view that welfare is constituted by the satisfaction of (actual) preferences. Sen explains the tendency to equate preferences and welfare as follows:

In the standard general equilibrium literature, individual preference orderings

... play two distinct parts, to wit: (i) they determine individual choices ... and

(ii) they represent individual welfares used as the basis of welfarist evaluations

of market equilibria... The two together amount to assuming that each per-

son's choices are guided solely by the maximization of her own welfare, that

is, by the self-interested pursuit of personal welfare. Sen $(2002,520)$.

Since one may wish to drop the assumption of self-interested behaviour, it is important, as Sen notes, that the 'basic analytical results relate directly to the fulfilment of preference satisfaction'. Someone who holds an informed desire or preference view would only accept the equivalence between (1) and (2) if the preferences in (2) are informed in the relevant sense. There are clearly cases where (1) and (2) can come apart so that the self-interest assumption is violated. One example would be where someone has a preference for smoking or for taking some drug but does not know of its harmful effects. Or it might be that someone knows that smoking or drug taking is harmful but is addicted to it and fails to choose according to their rational or informed preference.

If, by contrast, economists focus on people's actual desires or preferences in defining Pareto efficiency and treat (2) as the normative criterion for the evaluation of the market, they might indeed fall foul of the criticism that they 'assume that all values are merely subjective preferences not open to reasoned argument' (Sandel 2013, 121). By contrast, reasoning would be required on the informed desire or preference view and it would only be in the presence of informed rationality that economists would be able to make a claim about the market as a mechanism which promotes welfare. However, if one holds onto (1) and adopts the informed or rational preference view, one would also conclude that-in Harsanyi's terms - to the degree 
that people's 'manifest' preferences diverge from their 'informed' or 'true' preferences, market allocations may not be efficient in terms of welfare. If so, there is market failure and a case for government intervention to ensure that people make better informed and reasoned decisions. On this reading, even if the use of the informed desire view can help to defend the framework of welfare economics, it also emphasises the strong nature of the assumptions under which markets produce Pareto efficient outcomes. To this degree, this defence of welfare economics may weaken the case for the market.

Explicit recognition of the self-interest assumption, and violations of it, might lead economists and governments to intervene by, for example, providing consumers with information on the harmful effects of smoking, or of taking certain drugs. And further claims about violations of the self-interest assumption have emerged from the recent behavioural economics literature and have led to a variety of 'paternalistic' proposals advanced by Camerer et al. (2003) and Thaler and Sunstein (2008) inter alia (see also Conly 2013) which are motivated by behavioural economics. There is a question about how much intervention might be justified in this way on Harsanyi's view or by informed desire or preference views in general. Harsanyi was, to some degree, aware of the issue at the time he wrote his later papers. He distinguished 'positive paternalism' which 'would try coercively to prevent self-damaging behaviour'. He believed that-in a democratic society — such paternalism can be justified 'only in cases where such behavior would inflict utterly intolerable damage on the agent or would seriously damage innocent bystanders' (Harsanyi 1997, 134). By contrast, Harsanyi endorsed 'negative paternalism' which would 'refuse to help and to subsidize activities we consider to be against the agent's own interests' (Harsanyi 1997, 134). Harsanyi's remarks suggest that he would not endorse most coercive 'paternalistic' interventions but might potentially support 'libertarian paternalist' proposals, which interfere with choice without blocking freedom to choose. How many such interventions might be endorsed on his view? Qizilbash (2012) has argued that there may be significant limitations to the libertarian paternalistic agenda on an informed desire or preference view, notably if (as in Griffin's case) that view endorses some strong version of the value of autonomy which requires that people should be able to make their own mistakes. As a consequence, there may be a tension between the case for government intervention where preferences are irrational or ill-informed and a resistance to most forms of 'positive' or 'libertarian' paternalism. How might Harsanyi have responded to this tension? To the degree that there is a conflict, Harsanyi's position would most likely go beyond the standard framework of welfare economics in potentially trading off these two considerations on the basis of his version of rule-utilitarianism. ${ }^{4}$

\footnotetext{
4 The rule-utilitarian would no doubt take into account not merely the possibility that consumers are sometimes irrational or ill-informed but also that government officials and regulators may also be similarly irrational and ill-informed, even if we assume that they are benign (which they may not be). These considerations also imply a restriction of the libertarian paternalist agenda. On this point, see the 'ruleconsequentialist' argument discussed in Sunstein (2014, 116-122).
} 
Some economists might still defend market efficiency in terms of (2) even if it does not coincide with (1). Their reason might have to do with the idea that the ability to achieve a more preferred point reflects an increase in opportunity or freedom even if it does not coincide with an increase in welfare. ${ }^{5}$ One version of the case for the market which is based on reasoning of this sort was advanced by Sen (1993). On this version, the case for the efficiency of the market is made in terms of freedom understood as opportunity-freedom rather than welfare. I should note that the notion of opportunity-freedom here is primarily understood in terms of the opportunity to satisfy preferences (over commodities), rather than in terms of Sen's idea of 'capability' (e.g. Sen 1985) understood in terms of the range of lives-constituted by 'beings' and 'doings' which he terms 'functionings'-which one has reason to value and from which one can choose one. Sen has separately argued that capability, thus understood, might be relevant to the evaluation of the quality of life, egalitarian justice and development. In discussing the case for the market in terms of opportunity, Sen's basic claim is that if the market is, roughly speaking, efficient in terms of preference satisfaction, it is also plausibly efficient in terms of opportunity-freedom (to satisfy preferences). ${ }^{6}$ Can this claim be extended to suggest that the market generates capability efficiency? Sen believes that it can, because he thinks that the chief contribution of the capability approach is in areas where there are interpersonal comparisons of the quality of life. But in judgements of whether or not a distribution is Pareto efficient, such comparisons are not involved. As a consequence, there may be 'congruence between the budget sets in commodity space and the ranking of the corresponding capability sets in the functioning space' (Sen 2002, 523). Thus, he concludes that ' $[\mathrm{i}] \mathrm{f}$ this relationship is formally axiomatized, then ... efficiency of opportunity-freedoms in commodity space can be correspondingly extended to ... efficiency of opportunity-freedoms in the space of functionings' (Sen 2002, 523). Sen $(2002,524)$ does nonetheless add that if one accepts a capability perspective and evaluates distributional issues in terms of people's capability, the market may produce more inequality than would be observed in the standard framework where one focusses on preferences over commodities because of unequal advantages in converting commodities (or income) into capability (see Sen 2002, 524).

Sen's notion of efficiency in terms of opportunity-freedom allows one to defend the efficiency of the market even when the self-interest assumption is relaxed. It does not, however, entirely get rid of the problem of potentially problematic preferences. Indeed, one might still be worried about the kinds of freedom or opportunity that are promoted by the market. That thought is nonetheless not new to economists, since Sen $(1970,1979,2017)$ also made the point many years ago in his work on social choice (and on the 'Impossibility of the Paretian Liberal' in particular) that economists may need to examine the content and nature of the preferences that are used in evaluating states of affairs. If the opportunity-based case for the efficiency of the market relies on actual preferences, some economists might contend that there is reason to stress the limitations of the Pareto criterion.

\footnotetext{
5 Note that a rule-utilitarian may also make the case for the market in these terms. Here again the ruleutilitarian would be departing from the standard case in welfare economics.

6 In his paper, Sen's exact term is 'weak efficiency'. The precise terms and axioms which Sen uses in advancing this claim can be found in Sen (2002, 511-522).
} 
In terms of the informed desire or preference view, when Pareto efficiency is understood in terms of welfare, we must assume that consumer preferences are well informed and rational in some strong sense; while when the case is made in terms of preference alone, it must only assume that agents are rational to the degree that they have coherent preferences - preferences which meet certain standard axioms but satisfaction of which may not connect with their welfare. The second weaker requirement on the rationality of agents might be more realistic than the assumption that all agents are fully informed and rational. If that is so, and one wishes that the case for the market is based on more realistic assumptions about consumer preferences, one might favour an opportunity-based defence of the market. But going further, one might want to drop even the requirement that preferences are rational in the weaker sense that I have just explained-because of experimental work which suggests that preferences may not even be coherent. That is the approach which (Sugden 2004, 2017; see also McQuillin and Sugden 2012) takes in recent defences of the market based on the 'opportunity criterion'. Sugden's view is also interestingly different from those who advance the informed preference view. For Sugden, advantage is judged not in terms of informed preferences, but in terms of 'opportunity as mutual advantage'. This involves a person having the opportunity to choose whatever she might desire and be willing to pay for (Sugden 2010, 55). If the case for the market is made along these lines, the market furthers people's opportunity to choose whatever they might desire and are willing to pay for whether or not the relevant desires are informed or rational. This view of advantage is more libertarian than any views I have thus far discussed and Sugden (2010, 58-59) links it directly to J.S. Mill's work on liberty (and his 'harm principle' in particular). Anyone who wishes to look into the nature and content of preferences-whether this is a critic of mainstream economics or indeed a utilitarian-might potentially object to this defence of the market for a variety of reasons. But this defence of the market is quite distinct from the standard defence in traditional welfare economics, or even from Sen's view that markets promote opportunity-freedom. And Sandel might raise anti-libertarian objections to Sudgen's defence and its reliance on people's actual preferences. ${ }^{7}$ But those objections might not apply to standard welfare economics. Indeed, these differences between various defences of the market also illustrate the pluralistic nature of economics as a discipline and the different approaches that economists can take in responding to the criticisms levelled by Anderson and Sandel.

\section{Higher and lower goods and the corruption argument}

There are goods which, some argue, are priceless. Candidates include: dignity, friendship and love. Consider friendship. There is a family of different claims involved in arguments about this good. One is that friendship cannot be bought or sold: if it could be, it would not be friendship. Sandel $(2012,93)$ argues that this

\footnotetext{
${ }^{7}$ Sugden (2006) has explicitly defended the use of actual preferences.
} 
is a good that 'money can't buy'. ${ }^{8}$ That is hard to contest. There is a related argument which Sandel also advances: it claims that people are applying a price to a good whenever they weigh it against another good (e.g. Sandel 2012, 48-49). Some claim that some goods have no price in this sense. And this claim is harder to sustain. One might be attracted to a job in another town if it allows one more autonomy and accomplishment than the job one currently has and one might weigh the gain in these values against the loss in the time one spends with a good friend. So when we say that a good is priceless in this sense, friendship is not a priceless good: some amount of it can be weighed against other values.

In arguing that economics should only focus on lower pleasures, Jevons restricted the scope of economics on the basis of similar arguments. Having concluded that all human motives can be treated as pleasures and pains, Jevons argued that it important to be able to make qualitative distinctions between them. He suggested that: 'the feelings of which a man is capable are of various grades' and he thought a 'higher motive may rightly overbalance all considerations belonging to the next lower stage'. There was, on this view, no basis for weighing lower feelings against higher ones: the higher feelings act as 'trumps' which can defeat lower feelings. Nonetheless, Jevons suggested that if there is no prohibition from higher feelings, then the lowest rank of feelings can be weighed against each other and economics provides a 'calculus of utility [which] aims at supplying the ordinary wants of man at the lowest cost of labour' (Jevons 1871, 92-3).

Might an argument of this sort be successfully advanced to restrict the range of modern economics? There are various reasons why this is unlikely. First, neoclassical economics has rejected its hedonist roots. And second, even if some distinction between 'higher-' and 'lower-order' goods could be successfully made along lines similar to those Jevons had in mind, any claim to the effect that 'higher-order' goods are lexically superior to, and act as 'trumps' which cannot be weighed against, 'lower-order' goods might appear to be elitist. But the claim of lexical superiority might also be implausible: it might be argued that there must be some sufficiently large amount of a good of 'lower order' which is worth more than, and so is preferable to, some very small amount of a 'higher-order' good.

While J.S. Mill's distinction between higher- and lower-order pleasures may not attract some modern economists, there are claims which have a similar flavour in the literature on informed desire or preference views. Here is an example from James Griffin's version of that view. Griffin (1986, 85-9) argues that that there may be some amount of one good-say, some amount of time enjoying Rembrandt's masterpieces — which, if properly appreciated - is preferred to any amount of time enjoying some much lower quality art, such as the lesser painters of the seventeenthcentury Dutch school. ${ }^{9}$ But even if one could plausibly make claims of this sortdistinguishing 'higher' and 'lower' enjoyments in the context of an informed desire view - that would hardly provide a plausible basis for distinguishing where economics or indeed market reasoning should or should not apply. There seems to be no

\footnotetext{
${ }^{8}$ Sandel $(2012,107)$ concedes, nonetheless, that money can buy 'tokens' and 'expressions' of friendship, though he thinks of these in terms of a 'degraded' form of the value.

${ }^{9}$ Griffin treats this as a case of 'discontinuity'. For another candidate example, see Skorupski (2000, 248).
} 
basis for arguing, for example, that the analysis of supply and demand should not apply to exhibitions of the work of Leonardo da Vinci or Rembrandt, while it does apply to some much lesser artists of their time.

Is there any other modern argument which can do some of the relevant work in restricting the scope of economics? Elizabeth Anderson provides an argument of this sort even though hers is not an argument about the scope of economics, but about the limits of markets. Anderson suggests that in some cases there might be a bar on trade-offs between various goods when one belongs to a higher category of value than another. Here what distinguishes a higher from a lower-order good relates to the norms which apply to each. She writes that:

Money, commodities, conveniences, luxuries, and sensual pleasures represent paradigmatic lower goods. They are not simply seen as less valuable, but as not even comparable on the same high scales as those on which paradigmatic higher goods such as human life, friendship, freedom and human rights are measured. (Anderson 1993, 66).

Anderson says of the higher goods that they are 'incomparable' to the lower, so that there is some form of 'hierarchical incommensurability' between the two categories of goods. She also claims that they are more valuable, which implies that they are comparable at least in terms of value. On Anderson's account, one good is of 'incomparably higher worth' than another if it is worthy of a higher mode of valuation than the other ...' and she adds that '[o]ne way of valuing something is higher than another if the things concerning it make deeper, qualitatively more significant demands on the attitudes, deliberations, and actions of the valuer' (Anderson 1993, 70). She thinks that 'one way to express the difference in demands is to prohibit trade-offs' (Anderson 1993, 70). This seems to imply the kind of qualitative difference and prohibition on trade-offs that Jevons thought is involved between different types of pleasure. Yet Anderson knows that there are cases where people do tradeoff values such as friendship, and where there is no reason to prohibit such a tradeoff. She writes:

It is usually no offence against a friend for one to move to a distant city to obtain a higher paying job, even if the friendship is attenuated because of reduced contact. But it is a betrayal for someone to accept another's offer of money on condition she not see her friend so often (Anderson 1993, 70).

So Anderson's claim is not that we cannot sometimes trade-off higher- and lowerorder goods of the sorts that she distinguishes, but only that trade-offs should sometimes be prohibited. The actual distinction between higher- and lower-order goods cannot be made in terms of (incommensurability understood as) a (complete) prohibition on trade-offs between these types of goods. ${ }^{10}$ Rather it has to do with the fact that different norms or kinds of valuation apply to different goods. And Anderson thinks that 'hierarchical incommensurability' can explain other intuitive ideas. One

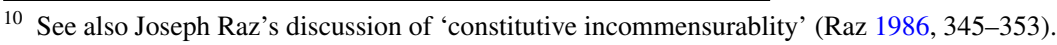


of these ideas involves 'valuing in a higher way things unworthy of all but lower modes of valuation'. Examples include: idolatry and 'commodity fetishism'. 'Commodity fetishism', according to Anderson, is a 'characteristic vice of capitalist societies, [and] consists in a blind devotion to consumer goods, attributing powers and values to them that are properly to be found in relations between people' (Anderson 1993, 71). In the opposite case, 'a practice is degrading when it expresses a lower valuation of something than it merits' and an example is slavery 'because in slavery, individuals are valued as mere commodities or use values' (Anderson 1993, 71). And this is the sort of mistaken attitude or reasoning which Sandel thinks might be at work when the introduction of the market can corrupt a good. As he puts it: "[t] o corrupt a good or social practice is to degrade it, to treat it according to a lower mode of valuation than is appropriate to it' (Sandel 2013, 126). And he treats such potential 'corruption' as a serious argument against the spread of market reasoning.

This line of argument can be addressed to economic analysis when it treats as commodities goods which are not appropriately understood as goods which can or should be exchanged in markets. The standard framework of welfare economics does not, however, make any claims about what does and does not count as a commodity: the set of commodities is taken as given. The argument might, nonetheless, have force when levelled at market enthusiasts. An example is Becker's theory of fertility. In that theory, Becker (1976) treats children as if they are consumer goods, and more specifically treats them as consumer durable goods. He notes that '[i]t may seem strained, artificial and perhaps even immoral to classify children with cars, houses, and machinery' and he adds 'this does not imply, however, that the satisfactions or costs associated with children are morally the same as those associated with other durables' (Becker 1976, 172-3). Analysing the choice of whether or not to have a child, or of how many children to have, in this way might lead people to value or think about children in the 'wrong' way. It might lead them to value them as tradeable commodities rather than objects of parental love (see Radin 1996, 7-8 and 13). That might 'corrupt' the value of personal relationships or of the value of parental love. There is an important argument here, one that needs careful consideration. ${ }^{11}$ But it is an argument against market enthusiasm of the sort Becker espoused, not against the general framework of welfare economics.

Anderson (1993, 164-6) nonetheless also claims that there are reasons why welfare economics encourages the spread of market norms. She argues that: "libertarianism and welfare economics represent most expansions of the domain of market norms as gains in freedom and welfare'. As regards welfare economics, Anderson provides no evidence of this. But she goes on to argue that the chief reasons why welfare economics does this relate to "three fundamental errors in its theory of

\footnotetext{
11 This point may also be addressed by Griffin's version of the informed desire view. On that view, one might well say that anyone who treats children or friends as tradeable commodities in the relevant way does not appreciate their value. Nonetheless, as with the value of dignity (see Griffin 1986, 82) my guess is that Griffin would admit that there are circumstances where people would trade-off some amount of these values, e.g. the amount of time spent with a friend versus the amount of time given to the writing of a book. Here it must be stressed that the different versions of the informed desire or preference view may sometimes differ in how they respond to some of these issues.
} 
value': (a) its preference orientation; (b) individualism; and (c) commodity fetishism. I want briefly to argue that if we understand welfare in terms of informed desire or preference, we might avoid the first of these and that there are resources within the traditional framework of welfare economics might also address the third. I shall not discuss the issue of individualism here. ${ }^{12}$ In (a), Anderson's claim is that welfare economics ties freedom and welfare to the expression or satisfaction of given preferences, rather than to the expression of rational attitudes. Yet if welfare is understood, as it is on some of the accounts I have discussed, in terms of informed desire or preference, relevant desires and preferences are expressions of rational attitudes. As regards commodity fetishism, Anderson $(1993,166)$ claims that it 'pervades the conception of human good embraced by welfare economics' because 'it defines a person's welfare as the satisfaction of her given preferences, which it conceives as automatically expressed in her choices and as taking exclusively appropriated goods as their basic objects'. However, if one takes an informed desire or preference view of welfare of the sort discussed here, then value resides in the objects of desire or preference. And the value of commodities would be understood in terms of their contribution to the realisation of those objects. Within the resources of traditional welfare economics, characteristics bridge the gap between commodities and the valued ends they serve.

It is nonetheless true that Anderson has pinpointed an important risk-that the framework of traditional welfare economics might be understood so that commodities are regarded as the ultimate objects of preference. The economics profession has itself responded to that risk by advancing frameworks-which include, aside from Lancaster's view, Sen's capability approach (1985)—which explicitly reject the idea that commodities are valuable in themselves. ${ }^{13}$ The characteristics of commodities are unsurprisingly also the starting point for Sen when he attempts to address the risk of 'commodity fetishism' in economics. In making the case for going beyond characteristics, Sen $(1985,6)$ writes that 'the characteristics of these goods do not tell us what the person will be able to do with these properties'. This observation is part of what motivates Sen's capability approach, since it leads him to consider what a person is able to do and be in leading a life. This point might be taken up within an informed desire or preference view by noting that while characteristics provide a bridge between commodities and the objects of ultimate value, what matters is their contribution to the realisation of those values and to welfare. To this degree, the informed preference view might also be able to do some of the work which Sen does by advancing his capability approach.

\footnotetext{
12 On the issue of 'individualism' defined in various ways and informed desire or preference views of well-being, see Qizilbash (2014).

13 Indeed, it is surprising that Anderson does not herself note this point in her discussion of welfare economics and 'commodity fetishism', given that in her subsequent work, Anderson (1999) endorses the capability approach in the context of egalitarian justice.
} 


\section{Conclusions}

Elizabeth Anderson and Michael Sandel have argued that market reasoning might extend beyond its rightful domain and 'corrupt' certain important values. Sandel thinks that part of the reason it might do so has to do with utilitarian logic and he encourages economists to connect with the roots of their discipline in moral and political philosophy. He argues that part of the failure of economics to provide a helpful view of what goods should and should not be up for sale lies in its ambition to be a value-free science. I have argued that, in developing neoclassical economics under the influence of the classical utilitarians, William Stanley Jevons made claims similar to those that Anderson and Sandel have advanced. So it is hard to trace the enthusiasm for market reasoning to the origins of neoclassical economics in utilitarian thought. Furthermore, inasmuch as the standard case for the market in welfare economics assumes that the set of commodities is given, it does not make any claims about what is and is not a commodity. Normative economics is not value free: it endorses multiple values without taking any definitive view of how to rank or weigh these. And economics allows for a variety of moral beliefs. In both these ways, it is value pluralist rather than value free.

Jevons' view that economics should be restricted to the lowest order of pleasures is hard to sustain in the landscape of modern economics. Anderson's view-which is a close relative of Jevons' - and the associated 'corruption' argument which Sandel has advanced suggest that market reasoning can lead us to value goods according to inappropriate norms. This argument has force when addressed to the work of market enthusiasts. It might also gain credibility on the grounds that economists treat commodities as valuable for themselves. Whatever its merits as an objection to market enthusiasm, the corruption argument has limited force as a critique of welfare economics as a normative framework. Furthermore, if one interprets the results of welfare economics in terms of the informed desire or preference view-some of the alleged weaknesses of economics which Anderson and Sandel mention can be rebutted. However, when people's preferences or desires are not fully informed or rational markets will not necessarily deliver efficiency in terms of welfare and there is an economic case for government intervention to facilitate better informed and reasoned choices. I have argued that this is one way in which economists might respond to Anderson and Sandel. But I have also stressed throughout that economics is a pluralist discipline, and economists might respond in quite different ways to these critics. An alternative line of response-developed in different ways by Sen and Sugden-would instead suggest that markets promote opportunity rather than welfare.

Open Access This article is distributed under the terms of the Creative Commons Attribution 4.0 International License (http://creativecommons.org/licenses/by/4.0/), which permits unrestricted use, distribution, and reproduction in any medium, provided you give appropriate credit to the original author(s) and the source, provide a link to the Creative Commons license, and indicate if changes were made. 


\section{References}

Anderson E (1993) Value in ethics and economics. CUP, Cambridge

Anderson E (1999) What is the point of equality? Ethics 109:287-337

Arrow K (1951) An extension of the basic theorems of classical welfare economics proceedings of the second berkeley symposium on mathematical statistics and probability Berkeley. California: University of California Press

Arrow K (1997) Invaluable goods. J Econ Lit XXXV:757-765

Arrow K, Hahn F (1971) General competitive analysis. Holden Day, San Francisco

Becker G (1976) The economic approach to human behavior. University of Chicago Press, Chicago

Besley T (2012) What is the good of the market? An Essay on Michael Sandel's What Money Can't Buy. J Econ Lit 51:478-495

Camerer C, Issacharoff S, Lowenstein G, O’Donohue T, Rabin M (2003) Regulation for conservatives: behavioral economics and the case for asymmetric paternalism. Univ Pa Law Rev 151:1211-1254

Conly S (2013) Against autonomy: justifying coercive paternalism. Cambridge University Press, Cambridge

Gorman W (1956) The demand for related goods Journal Paper J3129. Iowa Experimental Station, Ames

Griffin J (1986) Well-being: its meaning, measurement and moral importance. Clarendon Press, Oxford

Harsanyi J (1953) Cardinal utility in welfare economics and in the theory of risk taking. J Polit Econ 61:434-435

Harsanyi J (1955) Cardinal welfare, individualistic ethics and interpersonal comparisons of utility. J Political Econ 63:309-321

Harsanyi J (1982) Morality and the theory of rational behavior. In: Sen A, Williams B (eds) Utilitarianism and beyond. Cambridge University Press, Cambridge

Harsanyi J (1995) A theory of prudential value and a rule utilitarian theory of morality. Soc Choice Welfare 12:319-333

Harsanyi J (1997) Utilities preferences and substantive goods. Soc Choice Welfare 14:129-145

Hausman D (2012) Preference, value, choice and welfare. Cambridge University Press, Cambridge

Hausman D, McPherson M (2009) Preference satisfaction and welfare economics. Econ Philos $25: 1-25$

Hicks J (1939) Value and capital. An inquiry into some fundamental principles of economic theory. Oxford University Press, Oxford

Jevons WS (1871) The theory of political economy. Penguin, Harmondsworth

Lancaster K (1966) A new approach to consumer theory. J Polit Econ 74:132-157

Layard R (2005) Happiness: lessons from a new science. Allen Lane, London

Mill JS (1962) Utilitarianism. On liberty. Essay on Bentham together with selected writings of Jeremy Bentham and John Austin. In: Mary W (Ed.) Introduction. Glasgow: William Collins Sons \& Co

Qizilbash M (2005) Incommensurability and the first fundamental welfare theorem. Oxford Economic Papers 57:664-673

Qizilbash M (2012) Informed desire and the ambitions of libertarian paternalism. Soc Choice Welfare 38(4):647-658

Qizilbash M (2014) Are modern philosophical accounts of well-being excessively "individualistic"? Int Rev Econ 61:173-189

Radin M (1996) Contested commodities. The trouble with trade in sex, children, body parts and other things. Harvard University Press, Cambridge Mass

Raz J (1986) The morality of freedom. Clarendon Press, Oxford

Sandel M (2012) What money can't buy. The moral limits of the market. Penguin, London

Sandel M (2013) Market reasoning as moral reasoning: why economists should re-engage with political philosophy. J Econ Perspect 27:121-140

Sen A (1970) The impossibility of a paretian liberal. J Polit Econ 78:152-157

Sen A (1979) Collective choice and social welfare. North Holland, Amsterdam

Sen A (1984) Economics and the family. In: Resources, values and development. Oxford: Basil Blackwell

Sen A (1985) Commodities and capabilities. North-Holland, Amsterdam 
Sen A (1993) Markets and freedoms: achievements and limitations of the market mechanism in promoting individual freedom. Oxf Econ Papers 45:519-541

Sen A (2002) Rationality and freedom. Cambridge Mass. and London, England: the Belknap Press of Harvard University Press

Sen A (2017) Collective choice and social welfare. Penguin, London

Sidgwick H (1981) The methods of ethics. Hackett, Indianapolis

Skorupski J (2000) Quality of well-being: quality of being. In: Crisp R, Hooker B (eds) Well-being and morality: essays in honour of James Griffin. Clarendon Press, Oxford

Sugden R (2000) Review of Well-being and morality. Essays in honour of James Griffin Times higher education supplement

Sugden R (2004) The opportunity criterion: consumer sovereignty without the assumption of coherent preferences. Am Econ Rev 94:1014-1033

Sugden R (2006) Taking unconsidered preferences seriously. Philosophy 59(Supplement):209-232

Sugden R (2010) Opportunity as mutual advantage. Econ Philos 26:47-68

Sugden R (2017) Characterising competitive equilibrium in terms of opportunity. Soc Choice Welfare 48:487-503

Sugden R, Bruni L (2013) Reclaiming virtue ethics for economics. J Econ Perspect 27:141-164

Sugden R, McQuillin B (2012) How the market responds to dynamically inconsistent preferences. Soc Choice Welfare 38:617-634

Sunstein C (2014) Why nudge? The politics of libertarian paternalism. Yale University Press, Yale

Thaler R, Sunstein C (2008) Nudge: improving decisions about health. Penguin, Wealth and Happiness London 